Volume 2 Nomor 1, Januari-Juni 2018: hlm. 1-20. Magister Ilmu Hukum, Fakultas Hukum, Universitas Lampung, Bandar Lampung, Lampung, Indonesia.

E-ISSN: 2598-3105 P-ISSN: 2723-2581

http://jurnal.fh.unila.ac.id/index.php/cepalo

\title{
KAJIAN HARMONISASI HUKUM PERSAINGAN TIGA NEGARA ANGGOTA ASEAN BERDASARKAN THE ASEAN REGIONAL GUIDELINES ON COMPETITION POLICY
}

\author{
STUDY OF HARMONIZATION OF COMPETITION LAWS OF THREE ASEAN \\ MEMBER COUNTRIES BASED ON THE ASEAN REGIONAL GUIDELINES ON \\ COMPETITION POLICY
}

\author{
Abdul Muthalib Tahar \\ Universitas Bandar Lampung \\ abdul.muthalib@fh.unila.ac.id \\ S. Endang Prasetyawati \\ Universitas Bandar Lampung \\ Endang.dosenubl@gmail.com
}

\begin{abstract}
Abstrak
Komunitas Ekonomi ASEAN (KEA) merupakan salah satu pilar dari dua pilar lainnya yang dihasilkan oleh KTT ASEAN pada Oktober 2003 di Bali. Pada KTT ASEAN ke-12 para pemimpin menguatkan komitmen untuk mempercepat pembentukan Komunitas ASEAN pada tahun 2015 agar sejalan dengan Visi ASEAN 2020 dan Bali Concord II, dan sekaligus menandatangani Cebu Declaration on Acceleration of the Establishment of an ASEAN Community by 2015. Untuk mewujudkan pembentukan KEA perlu menyusun suatu cetak biru (blueprint) atau disebut Deklarasi Cetak Biru Komunitas Ekonomi ASEAN. Terdapat empat karakteristik dalam Blueprint, di mana karakteristik kedua dalam Cetak Biru KEA, yaitu menciptakan ASEAN sebagai kawasan yang berdaya saing tinggi di bidang ekonomi (Kawasan Ekonomi yang Kompetitif). Guna merealisasikan hal tersebut Cetak Biru menetapkan ketentuan tentang Kebijakan Persaingan Usaha yang pada tahun 2010 pedoman ini berhasil dirumuskan dan dinamakan Regional Guidelines on Competition Policy (Regional Guidelines). Dengan adanya Regional Guidelines ini maka Negara-negara anggota ASEAN harus menyesuaikan perundang-undangan persaingan nasionalnya. Dari tiga negara anggota ASEAN yang diteliti (Indonesia, Malaysia, dan Singapura) berdasarkan indikator dalam penyusunan undang-undang persaingan, untuk Indonesia masih ada enam indikator yang belum sesuai (harmonis), sedangkan untuk Malaysia dan Singapura masing-masing masih ada dua indikator yang belum sesuai (harmonis). Dalam penulisan ini digunakan metode hukum normatif dengan pendekatan yuridis normatif dengan jenis penelitian deskriptif analitis dan studi komparasi. Penelitian ini menggunakan sumber data dari literatur, artikel dan situs-situs internet.
\end{abstract}

Kata Kunci: Blueprint, Regional Guidelines, Undang-Undang Persaingan.

\footnotetext{
Abstract

The ASEAN Economic Community is one of the two pillars produced by the ASEAN Summit in October 2003 in Bali. At the meeting the leaders strengthened their commitment to accelerate the formation of the ASEAN Community in 2015 to be in line with the Vision of the ASEAN 2020 and Bali Concord II, and at the same time sign the Cebu Declaration on Acceleration of the Establishment of an ASEAN Community by 2015. To realize the establishment of KEA it is necessary to arrange a blueprint or called the ASEAN Economic Community Blueprint Declaration. There are four characteristics in Blueprint, where the second characteristic in the
} 
KEA Blueprint, namely creating ASEAN as a region that is highly competitive in the economic field (Competitive Economic Zone). To realize this, the Blueprint stipulates the provisions on the Business Competition Policy which in 2010 this guideline was successfully formulated and named the Regional Guidelines on Competition Policy (Regional Guidelines). With the existence of these Regional Guidelines, ASEAN member countries must adjust national competition legislation. Of the three ASEAN member countries studied (Indonesia, Malaysia and Singapore) based on indicators in the preparation of competition laws, for Indonesia there are still six indicators that are not yet harmonious, while for Malaysia and Singapore each of them still has two indicators. not appropriate (harmonious). In this writing the normative legal method is used with a normative juridical approach with descriptive analytical research and comparative studies. This study uses data sources from literature, articles and internet sites.

Keywords: Blueprint, Regional Guidelines, Competition Law.

Cara Mengutip (How to Cite): Abdul Muthalib Tahar, S. Endang Prasetyawati, "Kajian Harmonisasi Hukum Persaingan Tiga Negara Anggota Asean Berdasarkan the Asean Regional Guidelines on Competition Policy”, Jurnal Cepalo, 2 (1), (2018): 1-20

DOI: https://doi.org/10.25041/cepalo.v2no1.1758

\section{A. Pendahuluan}

Pada tanggal 5 sampai 8 Agustus di Bangkok, berlangsung pertemuan antarmenteri luar negeri dari lima negara, yakni Indonesia, Malaysia, Singapura, Filipina, serta tuan rumah Thailand. Pada akhir pertemuan tepatnya di tanggal 8 Agustus 1967 para menteri luar negeri tersebut dari kelima negara tersebut menandatangani suatu deklarasi yang dikenal sebagai Deklarasi Bangkok (Bangkok Declaration). Deklarasi tersebut merupakan wujud persetujuan kesatuan tekad dari kelima negara tersebut untuk membentuk suatu organisasi kerja sama regional yang disebut Association of South East Asian Nations (ASEAN). Tujuan ASEAN didirikan sesuai Deklarasi Bangkok adalah: (i) percepatan pertumbuhan ekonomi, kemajuan sosial dan perkembangan kebudayaan di kawasan Asia Tenggara; (ii) meningkatkan stabilisasi dan perdamaian regional di Asia Tenggara. (iii) mendorong kerjasama yang aktif dan saling membantu di negara-negara anggota baik dalam bidang ekonomi, sosial, budaya, teknik, maupun ilmu pengetahuan dan administrasi; (iv) memberikan bantuan satu sama laindalam bentuk fasilitas-fasilitas latihan serta penelitian; (v) menciptakan kerjasama yang lebih besar dalam bidang pertanian, industri, perdagangan, pengangkutan, komunikasi serta usaha peningkatan standar kehidupan rakyatnya; (vi) meningkatkan studi-studi tentang masalah Asia Tenggara; dan (vii) memelihara dan memajukan kerjasama yang bermanfaat dengan organisasiorganisasi regional dan internasional yang ada.

Berdasarkan pada 7 (tujuh) pasal Deklarasi Bangkok itu, jelas menggambarkan bahwa ASEAN adalah organisasi kerjasama negara-negara Asia Tenggara yang bersifat non politik dan non militer, dan lebih menekankan kerjasama di bidang ekonomi. Deklarasi Bangkok ini kemudian diganti dengan Piagam Asean (Asean Charter) melalui KTT Asean yang ditandatangani pada tanggal 20 November $2007 .{ }^{1}$

\footnotetext{
1 Berdasarkan Asean Chater tujuan ASEAN sebagai berikut: (i) memelihara dan meningkatkan perdamaian, keamanan, dan stabilitas serta lebih memperkuat nilai-nilai yang berorientasi pada perdamaian di kawasan; (ii) meningkatkan ketahanan kawasan dengan memajukan kerja sama politik, keamanan, ekonomi, dan sosial budaya yang lebih luas; (iii) mempertahankan Asia Tenggara sebagai Kawasan Bebas Senjata Nuklir dan bebas dari semua jenis senjata pemusnah massal lainnya; (iv) menjamin bahwa rakyat dan Negara-Negara Anggota ASEA hidup damai dengan dunia secara keseluruhan di lingkungan yang adil, demokratis, dan harmonis; (v) menciptakan pasar tunggal dan basis produksi yang stabil, makmur, sangat kompetitif, dan terintegrasi secara ekonomis melalui fasilitasi yang efektif untuk perdagangan dan investasi, yang di dalamnya terdapat arus lalu lintas barang, jasa-jasa dan investasi yang bebas; terfasilitasinya pergerakan pelaku usaha, pekerja profesional, pekerja berbakat dan buruh; dan arus modal yang lebih bebas; (vi) mengurangi kemiskinan dan mempersempit kesenjangan pembangunan di ASEAN melalui bantuandankerjasamatimbalbalik; (vii) memperkuat demokrasi, meningkatkan tata kepemerintahan yang baik dan aturan hukum, dan memajukan serta melindungi hak asasi manusia dan kebebasan-
} 
Dalam upaya mewujudkan tujuan ASEAN khususnya di bidang ekonomi, pada KTT ASEAN di Kuala Lumpur Desember 1997 pemimpin ASEAN pada KTT ASEAN memutuskan untuk mentransformasikan ASEAN menjadi kawasan yang stabil, makmur, dan berdaya saing tinggi dengan peningkatan pembangunan ekonomi yang merata serta kesenjangan sosial ekonomi dan kemiskinan yang semakin berkurang. Selanjutnya pada KTT ASEAN yang diselenggarakan di Bali Oktober 2003 (Bali Concord II), Para pemimpin ASEAN mendeklarasikan tiga konsep komunitas ASEAN yang terdiri atas tiga pilar, yaitu (i) Komunitas Keamanan ASEAN (ASEAN Security Community), (ii) Komunitas Ekonomi ASEAN (KEA) (ASEAN Economy Community); (iii) Komunitas Sosial Budaya (ASEAN Socio-Cultural Community). ${ }^{2}$ Ketiga pilar tersebut diharapkan agar dapat bekerja secara sinergis dalam pembentukan Komunitas ASEAN pada tahun 2020.

Berikutnya pada pertemuan ke-38 Menteri Ekonomi ASEAN yang diselenggarakan di Kuala Lumpur, pada Agustus 2006, para Menteri Ekonomi ASEAN sepakat akan menyusun "sebuah cetak biru yang terpadu guna mempercepat pembentukan KEA dengan mengindetifikasi berbagai karakteristik dan elemen KEA pada tahun 2015 sesuai Bali Concord II, sasaran dan kerangka waktu yang jelas dalam mengimplementasikan berbagai langkah serta fleksibilitas yang telah disepakati sebelumnya untuk mengkomodir kepentingan seluruh negara anggota ASEAN. Para pemimpin ASEAN Pada KTT ASEAN Ke-12 menegaskan komitmen untuk mempercepat pembentukan Komunitas ASEAN pada tahun 2015 berkesinambungan dengan Visi ASEAN 2020 dan BALI CONCORD II, dan menandatangani Cebu Declaration on Acceleration of the Establishment of an ASEAN Community by 2015.

Komunitas Ekonomi Asean adalah sebagai bentuk realisasi tujuan akhir terintegrasinya ekonomi sesuai dengan visi ASEAN 2020, yang didasarkan pada kepentingan bersama Negara Anggota ASEAN untuk mempertegas dan memperluas integrasi ekonomi melalui inisiatif yang telah ada dan inisiatif baru dengan kerangka waktu yang lebih jelas. Dalam pembentukan KEA, ASEAN harus melaksanakan kewajiban yang sesuai dengan prinsip-prinsip ekonomi yang terbuka, berwawasan keluar, inklusif, serta berorientasi pada pasar, sehingga sesuai dengan aturan- aturan multilateral dan juga patuh terhadap sistem berdasarkan aturan hukum agar pemenuhan dan implementasi komitmen-komitmen ekonomi daat berjalan efektif. Dengan adanya KEA, doharapkan akan menjadikan ASEAN sebagai salah satu pasar tunggal yang berbasis produksi serta menjadikan ASEAN lebih dinamis dan kompetitif dengan langkah dan mekanisme yang baru dalam upaya memperkuat implementasi inisiatif-inisiatif ekonomi yang telah ada; mempercepat terintegrasinya kawasan dalam sektor-sektor prioritas; memberikan kemudahan untuk melakuka pergerakan bagi para pelaku usaha tenaga kerja terampil dan berbakat serta memperkuat mekanisme institus ASEAN.

Rencana penyusunan suatu cetak biru pembentukan KEA sudah dimulai pada pertemuan ke-38 Menteri Ekonomi ASEAN yang diselenggarakan di Kuala Lumpur, Malaysia, yang kemudian berhasil disusun dan disahkan pada Agustus 2006 pada KTT Asean yang diadakan di Singapura tanggal 20 November 2007 dengan nama Deklarasi Cetak Biru Komunitas Ekonomi

kebebasan fundamental, dengan memperhatikan hak-hak dan kewajiban-kewajiban dari Negara-Negara Anggota ASEAN; (viii) menanggapi secara efektif, sesuai dengan prinsip keamanan menyeluruh, segala bentuk ancaman, kejahatan lintas-negara dan tantangan lintas-batas; (ix) memaju-kan pembangunan berkelanjutan untuk menjamin perlindungan lingkungan hidup di kawasan, sumber daya alam yang berkelanjutan, pelestarian warisan budaya, dan kehidupan rakyat yang berkualitas tinggi; (x) mengembang-kan sumber daya manusia melalui kerja sama yang lebih erat di bidang pendidikan dan pemelajaran sepanjang hayat, serta di bidang ilmu pengetahuan dan teknologi, untuk pemberdayaan rakyat ASEAN dan penguatan Komunitas ASEAN; (xi) meningkatkan kesejahteraan dan penghidupan yang layak bagi rakyat ASEAN melalui penyediaan akses yang setara terhadap peluang pembangunan sumber daya manusia, kesejahteraan sosial, dan keadilan; (xii) memperkuat kerja sama dalam membangun lingkungan yang aman dan terjamin bebas dari narkotika dan obat-obat terlarang bagi rakyat ASEAN; (xiii) memajukan ASEAN yang berorientasi kepada rakyat yang di dalamnya seluruh lapisan masyarakat didorong untuk berpartisipasi dalam, dan memperoleh manfaat dari, proses integrasi dan pembangunan komunitas ASEAN; (xiv) memajukan identitas ASEAN dengan meningkatkan kesadaran yang lebih tinggi akan keanekaragaman budaya dan warisan kawasan; dan (xv) mempertahankan sentralitas dan peran proaktif ASEAN sebagai kekuatan penggerak utama dalam hubungan dan kerja samanya dengan para mitra eksternal dalam arsitektur kawasan yang terbuka, transparan, dan inklusif.

${ }^{2}$ Diakses dari https:ongkydenny.wordpress.com/2013/03/21/kttasean-dan-hasil-ktt/, tanggal 30 April 2018. 
Asean. Berdasarkan Deklarasi Cetak Biru KEA ini setiap negara anggota ASEAN diwajibkan untuk mematuhi dan mengimplementasikan KEA pada tahun 2015. Cetak Biru KEA akan mentransformasikan ASEAN menjadi sebuah pasar dan basis produksi tunggal, kawasan ekonomi dengan daya saing tinggi, kawasan dengan pembangunan ekonomi yang merata serta kawasan yang secara penuh terintegrasi ke dalam ekonomi global. Cetak Biru KEA pun memuat jadwal strategis dan terlampirkan dalam Deklarasi tersebut. Cetak Biru KEA ini harus diimplementasikan oleh para menteri terkait Negara-negara Anggota ASEAN yang akan dibantu oleh Sekretariat Asean dan melaporkannya secara berkala kepada KTT melalui Dewan Komunitas Ekonomi ASEAN, mengenai kemajuan dari implementasi tersebut.

Cetak Biru KEA mempunyai karakteristik utama yakni sebagai berikut : (a) Pasar tunggal dan memiliki basis produksi, (b) kawasan ekonomi dengan daya saing tinggi, (c) Kawasan dengan pembangunan ekonomi yang merata, (d) Kawasan yang terintegrasi penuh dengan ekonomi global. Karakteristik-karakteristik tersebut memiliki kaitan yang erat dan saling memperkuat untuk satu sama lainnya. Pencatuman elemen-elemen diperlukan untuk setiap karakteristik, dalam satu Cetak Biru akan memberikan jaminan terhadap konsistensi dan keterpaduan elemen-elemen tersebut. Termasuk implementasinya serta koordinasinya yang tepat antarpemangku kepentingan. Sebagaimana telah diuraikan sebelumnya, yang menjadi karakteristik kedua dalam Cetak Biru KEA, yaitu ASEAN sebagai kawasan ekonomi yang dengan daya saing tinggi (Kawasan Ekonomi yang Kompetitif). Dalam hal ini, Cetak Biru menetapkan ketentuan mengenai Kebijakan Persaingan Usaha, dengan tujuan utamanya yaitu gun memperkuat budaya persaingan yang sehat. Meskipun institusi dan perundang-undangan yang terkait dengan kabijakan persaingan usaha baru-baru ini telah terbentuk di beberapa Negara ASEAN, akan tetapi pada saat ini belum ada badan resmi ASEAN untuk menangani kerja sama CPL (Competition Policy Law) yang berfungsi sebagai jaringan agar badan-badan persaingan usaha atau badan terkait dapat melakukan tukar-menukar pengalaman dan normanorma institusional mengenai CPL.

Adapun langkah-langkah dan tindakan yang telah digariskan dalam Cetak Biru KEA mengenai Kebijakan Persaingan Usaha ini sebagai berikut: (i) Mengupayakan kebijakan persaingan usaha pada seluruh Negara ASEAN selambat-lambatnya pada 2015; (ii) Membentuk jaringan otoritas atau badan-badan yang berwenang atas kebijakan persaingan usaha sebagai forum untuk membahas dan mengkoordinasi kebijakan persaingan usaha; (iii) Mendorong program/kegiatan peningkatkan kemampuan bagi Negara Anggota ASEAN dalam menggembangkan kebijakan nasional persaingan usaha; dan (iv) Mengembangkan pedoman kawasan mengenai kebijakan persaingan usaha selambat-lambatnya pada 2010, berdasarkan pada pengalaman masing-masing Negara dan praktik-praktik internasional yang terbaik dalam rangka menciptakan iklim persaingan usaha.

Dalam kaitannya dengan Kebijakan Persaingan Usaha ini Pertemuan Menteri-menteri Ekonomi Asean ke 39 pada bulan Agustus 2007 telah memutuskan menyusun The ASEAN Regional Guidelines on Competition Policy (Regional Guidelines). Demikian pula Cetak Biru KEA mengenai Kebijakan Persaingan Usaha, point keempat menentukan pengembangan pedoman kawasan tentang kebijakan persaingan usaha untuk selambat-lambatnya pada tahun 2010. Terhadap kebijakan ini, akhirnya The ASEAN Regional Guidelines on Competition Policy (Regional Guidelines) berhasil disusun oleh the ASEAN Experts Group on Competition (AEGC), pada tahun 2010. Adapun yang dimaksud dengan kebijakan persaingan usaha (competition policy) dalam Regional Guidelines didefiniskan sebagai tindakan pemerintah yang secara langsung dapat mempengaruhi perilaku perusahaan, struktur industry dan pasar. Competition policy secara mendasar mencakup dua element, element pertama meliputi menempatkan seperangkat kebijakan yang memajukan persaingan usaha; dan element kedua adalah hokum persaingan usaha (competition law), menunjuk pada tindakan hokum (dalam bentuk legislasi, keputusan hakim dan regulasi) bertujuan pada pengawasan atau larangan praktik anti persaingan usaha.

Dalam kaitannya dengan element kedua ini, negara-negara anggota ASEAN pada umumnya sudah memiliki Undang-undang mengemukakan lima Negara Asean utama (Negara pendiri Asean) antara lain (i) Indonesia, yaitu UU No. 5 Tahun 1999 tentang Larangan Praktek 
Monopoli dan Persaingan Usaha Tidak Sehat; (ii) Singapura, yaitu Act 46 of 2004 - Competition Act 2004, kemudian diamandemen dengan Act 40 of 2005-Competition Act 2005, berlaku tanggal 1 Januari 2006; (iii) Malaysia, Laws of M alaysia, Act 712 Competition Act 2010; (iv) Thailand, yaitu Competition Act B.E 2542 (1999) yang kemudian diamandemen dengan Act B.E 2560 (2017); dan (v) Philipina, yaitu Republic Act No. 10667 and Its Implementing Rules and Regulations, tanggal 31 Mei 2016. Akan tetapi dalam tulisan ini yang akan dikaji hanya tiga undang-undang persaingan dari tiga Negara yaitu Indonesia, Malaysia, dan Singapura dengan alasan ketiga Negara ini Negara berkembang yang pertumbuhan ekonominya (perdagangan dan industri) sangat mapan.

Permasalahannya adalah dengan adanya The ASEAN Regional Guidelines on Competition Policy (Regional Guidelines), apakah undang-undang persaingan ketiga Negara anggota Asean ini sudah selaras (harmonis) dengan ketentuan yang digariskan dalam Regional Guidelines? Dalam penulisan ini digunakan metode hukum normatif dengan pendekatan yuridis normatif dengan jenis penelitian deskriptif analitis dan studi komparasi. Penelitian ini menggunakan sumber data dari literatur, artikel dan situs-situs internet.

\section{B. Pembahasan}

\section{The ASEAN Regional Guidelines on Competition Policy (Regional Guidelines)}

The ASEAN Regional Guidelines on Competition Policy (Regional Guidelines) merupakan pedoman bagi Negara-negara Anggota ASEAN dalam melaksanakan Komunitas Ekonomi ASEAN pada tahun 2015 yang program-programnya disusun dalam suatu dokumen yang disebut Deklarasi Cetak Biru (Blueprint) KEA, khususnya yang berkaitan dengan karakteristik kedua dalam Cetak Biru KEA, yaitu ASEAN sebagai kawasan ekonomi dengan daya saing yang tinggi (Kawasan Ekonomi yang Kompetitif). Dalam kaitan ini Cetak Biru menetapkan ketentuan tentang Kebijakan Persaingan Usaha, di mana tujuan ditetapkannya kebijakan ini adalah sebagai upaya untuk memperkuat budaya persaingan yang sehat.

The ASEAN Regional Guidelines on Competition Policy (Regional Guidelines) terdiri atas 10 Bab, yaitu (1) Objectives of Regional Guidelines; (2) Objectives and Benefits of Competition Policy; (3) Scope of Competition Policy and Law; (4) Role and Responsibilities of Competition Regulatory Body/Institutional Structure/Sector Regulators; (5) Legislation and Guidelines/Transitional Provisions; (6) Enforcement Powers; (7) Due Process; (8) Technical Assistance and Capacity Building; (9) Advocasy/Outreach; dan (10) International Cooperation/Common Competition Related Provisions in Free Trade Agreements. Dari sepuluh Bab yang diatur dalam Regional Guidelines ini yang akan dikaji hanya mengenai (1) Objectives and Benefits of Competition Policy; (2) Scope of Competition Policy and Law; dan (3) Legislation and Guidelines/Transitional Provisions; dengan alasan ketiga hal inilah yang sangat relevan dalam pembentukan undang-undang tentang persaingan usaha.

\section{a. Objectives and Benefits of Competition Policy (Tujuan dan Manfaat KebijakanPersaingan)}

1) Definisi Kebijakan Persaingan.

Kebijakan persaingan memiliki definisi yang luas sebagai bentuk kebijakan pemerintah dalam rangka memajukan atau memelihara tingkat persaingan di pasar, meliputi tindakantindakan pemerintah yang secara langsung dapat dan akan mempengaruhi perilaku perusahaan, struktur industri dan pasar. Kebijakan persaingan ini secara mendasar mencakup dua elemen (unsur), yaitu: (i) mencakup penetapan seperangkat kebijakan untuk memajukan persaingan di pasar local dan nasional, seperti kebijakan perdagangan yang lebih baik, menghapus kebijakan yang menghalangi praktik perdagangan, mendukung kemudahan akses keluar masuk pasar, berkurangnya campur tangan pemerintah yang memang tidak diperlukan dan mempercayakannya pada kekuatan pasar; (ii) yang dikenal sebagai hokum persaingan, mencakup peraturan perundang-undangan, peraturan dan putusan pengadilan yang secara khusus ditujukan untuk mencegah persaingan bisnis atau usaha yang tidak sehat, penyalahgunaan kekuatan pasar, dan tindakan anti persaingan usaha. 
Istilah "kebijakan persaingan" yang dimaksud dalam The Regional Guidelines menunjuk kepada kebijakan publik dan petunjuk (aturan) umum pemerintah yang bertujuan untuk memperkenalkan, meningkatkan dan/atau mempertahankan persaingan. Hal tersebut termasuk tetapi tidak terbatas pada hokum persaingan yang khususnya mengacu pada tindakan hokum (dalam bentuk peraturan perundang-undangan, aturan, panduan, dan lain-lain), termasuk membentuk dan mempertahankan badan pengawas persaingan untuk mencegah terjadinya tindakan anti persaingan pada praktik bisnis, penyalahgunaan kekuatan pasar dan tindakan anti persaingan pada merger.

a) Tujuan Utama Kebijakan Persaingan

1) Menjadi tujuan paling umum dalam kebijakan persaingan (competition policy) adalah meningkatkan dan melindungi setiap proses dalam persaingan tersebut. Kebijakan persaingan memperkenalkan - level-playing field $^{3}$ bagi semua pemain di pasar yang dapat mendorong pasar menjadi semakin bersaing. Melalui cara ini, dapat mencapai persaingan dengan adil atau efektif, dan juga kontribusiterhadap peningkatan efesiensi ekonomi, pertumbuhan, dan pembangunan ekonomi serta kesejahteraan untuk konsumen.

2) Kebijakan persaingan bermanfaat untuk Negara-negara berkembang. Disebabkan oleh deregulasi, privatisasi dan liberalisasi pasar di seluruh dunia, Negara-negara berkembang membutuhkan suatu kebijakan persaingan, bertujuan untuk mengendalikan dan mengontrol pertumbuhan peran sector swasta dalam perekonomian untuk menjamin tidak terjadi monopoli.

3) Di samping berkontribusi terhadap perdagangan dan kebijakan investasi, kebijakan kompetisi untuk mengakomodasi tujuan kebijakan lain (ekonomi dan social), seperti integrasi pasar nasional dan peningkatan integrasi regional, peningkatan atau perlindungan usaha kecil, kemajuan teknologi, peningkatan inovasi proses dan produk, kemajuan diversifikasi industry, perlindungan lingkungan, mengurangi inflasi, penciptaan lapangan kerja, perlakuan yang sama terhadap pekerja sesuai ras, gender serta kesejahteraan kelompok konsumen. Secara khusus kebijakan persaingan memiliki dampak yang positif bagi ketenagakerjaan, mengurangi jumlah tenaga kerja yang berlebih serta mendukung terciptanya lapangan kerja baru oleh competitor yang berdaya saing.

4) Melengkapi kebijakan perdagangan, kebijakan industry, dan mereformasi aturan. Kebijakan persaingan bersasaran perilaku pengusaha yang akan membatasi akses pasar serta mengurangi persaingan yang actual dan potensial, sedangkan kebijakan perdagangan dan industri meningkatkan kesesuaian terhadap struktur perdagangan dan industri dengan maksud memajukan peroduktivitas berdasarkan pertumbuhan dan reformasi aturan untuk mengakhiri pengaturan domestik yang membatasi masuk dan keluar pasar. Efektivitas kebijakan persaingan juga diharapkan dapat meningkatkan kepercayaan investor dan mencegah kehilangan keuntungan perdagangan melalui praktik anti persaingan usaha. Melalui cara ini, kebijakan persaingan dapat menjadi suatu factor penting dalam meningkatkan daya tarik ekonomi untuk penanaman modal asing langsung (direct investmen) dan meningkatkan keuntungan penanaman modal asing.

5) Masing-masing Negara Anggota Asean dapat memutuskan sasaran (tujuan) mana yang ingin dicapai, memperhitungkan kebutuhan kebijakan persaingan nasional miliknya.

b) Scope of Competition Policy and Law (Lingkup Hukum dan Kebijakan Persaingan). Adapun cakupan dari kebijakan persaingan nasional meliputi:

1) Larangan persetujuan-persetujuan (horizontal dan vertikal) anti persaingan, penyalahgunaan posisi dominan (kekuatan pasar), merger anti persaingan; dan

2) Larangan pembatasan praktik perdagangan lain.

\footnotetext{
${ }^{3}$ - a situation in which everyone has a fair and equal chance of succeeding $\|$ (suatu keadaan dalam mana setiap orang memiliki kesempatan yang adil dan sama untuk berhasil), dikutip dari en.oxforddictionaries.com.
} 
1) Larangan persetujuan-persetujuan anti persaingan.

Negara-negara anggota Asean dapat mempertimbangkan larangan persetujuan-persetujuan (horizontal dan vertikal) di antaranya usaha untuk mencegah, mengubah, membatasi persaingan di wilayah Negara anggota ASEAN, kecuali jika tidak dikecualikan dalam Bab ini. Persetujuan horizontal berarti suatu persetujuan yang diadakan antara dua atau lebih perusahaan yang beroperasi pada level yang sama di dalam pasar (contoh, suatu persetujuan oleh dua pabrik untuk memperbaiki harga penjualan dari suatu produk adalah persetujuan horizontal). Sedangkan persetujuan vertical adalah persetujuan yang diadakan oleh dua perusahaan atau lebih, yang mana setiap perusahaan memiliki peran dalam mencapai tujuan persetujuan tersebut, perusahaan tersebut berada pada level yang berbeda, seperti di rantai produksi dan distribusi, atau memperjual-belikan barang dan jasa (contohnya, persetujuan distribusi, agensi, dan waralaba).

Agreement memiliki arti luas dan meliputi persetujuan-persetujuan yang dapat diberlakukan (enforceable) dan tidak dapat diberlakukan ((non-enforceable) secara hokum, apakah secara tertulis atau oral; perjanjian ini meliputi apa yang disebut dengan (gentlemen's agreements). Suatu persetujuan dapat dicapai melalui pertemuan pisik dari para pihak atau melalui pertukaran surat atau melalui telepon atau dengan cara lainnya. Semua itu disaratkan bahwa para pihak sampai pada konsensus apakah masing-masing pihak memiliki kemauan untuk mengambil tindakan atau tidak —undertaking $\|$ berarti orang-orang, individu, suatu badan perusahaan, suatu badan non corporate, suatu badan bukan perkumpulan orang-orang atau suatu entitas lain yang mampu melaksanakan aktivitas perdagangan atau ekonomi yang berkaitan dengan barang-barang dan jasa. Hal itu termasuk individu-individu yang mengoperasikan sebagai pemilik tunggal, perusahaan, firma, kemitraan, koperasi, masyarakat, kamar dagang, asosiasi perdagangan dan organisasi-organisasi non-profit, apakah mereka legal dan memiliki status (asing atau local, pemerintah atau non-pemerintah).

Istilah (The terms) -prevent ll, -distortll or -restrictll refer, respectively, masing-masing, menunjuk, untuk menghapuskan keberadaan atau kegiatan-kegiatan persaingan, perubahan yang dibuat-buat tentang keadaan persaingan dalam mendukung pihak-pihak mengenai perjanjian, dan pengurangan kegiatan-kegiatan persaingan. Hal ini dimaksudkan mencakup semua keadaankeadaan dimana kondisi persaingan merugikan yang dipengaruhi oleh keberadaan dari persetujuan (perjanjian) anti persaingan.

Perjanjian-perjanjian antara-undertakings\| mungkin dikatakan membatasi kebebasan bertindak dari para pihak. Untuk itu Negara-negara anggota Asean akan mengevaluasi perjanjian itu melalui referensi terhadap objeknya atau terhadap pengaruhnya di mana mungkin. Negara-negara anggota Asean dapat memutuskan bahwa suatu perjanjian melanggar hokum hanya jika perjanjian itu memiliki sebagai obyeknya atau berpengaruh besar dalam pencegahan, penyimpangan atau pembatasan terhadap persaingan. Hal-hal yang berdampak pada persaingan misalnya price fixing, bid-rigging, market sharing, limiting or controlling ptoduction or investment, tindakan demikian dikatakan illegal.

\section{2) Larangan penyalahgunaan posisi dominan}

Negara-negara anggota ASEAN harus mempertimbangkan untuk melarang penyalahgunaan posisi dominan. Posisi dominan mengacu pada situasi pasar, di mana para pelaku usaha baik secara individu maupun bersama dengan pengusaha lain, berada dalam posisi untuk secara sepihak mempengaruhi parameter persaingan di pasar yang relevan terhadap barang dan jasa, misalnya, dapat menguntungkan mempertahankan harga di atas tingkat persaingan atau untuk membatasi output ata kualitas di bawah tingkat persaingan. Adapun langkah yang tepat untuk mempertimbangkan dampak secara langsung atau yang akan datang dari perilaku di dalam persaingan, Negara-negara anggota Asean dapat memberikan contoh perilaku tersebut sebagai berikut:

- Perilaku eksploitatif terhadap konsumen, pelanggan dan/atau pesaing (misalnya harga penjualan dan pembelian yang berlebihan ata tidak adil, kondisi perdagangan yang tidak adil dan mengikat);

- Perilaku pengecualian terhadap pesaing (misalnya, predatory pricing oleh pelaku usaha 
yang dengan sengaja menimbulkan kerugian dalam jangka pendek dengan menetapkan harga yang sangat rendah sehingga memaksa satu atau lebih pengusaha keluar dari pasar, sehingga dapat menentapkan harga yang lebih tinggi dalam jangka panjang atau margin squeeze.

- Perilaku diskriminatif (misalnya, menerapkan harga atau ketentuan yang berbeda untuk transaksi yang setara dan sebaliknya). Membatasi produksi, pasar atau pengembangan teknis untuk merugikan konsumen (misalnya, membatasi produksi atau membuat tidak sah suatu barang yang sedang dikirim, membatasi akses terhadap penggunaan atau pengembangan teknologi baru.

3) Larangan Merger Anti Persaingan.

Larangan merger anti persaingan pada dasarnya merupakan kegiatan komersial yang sah antara penyelenggara di dalam perekonomian. Akan tetapi Negara-negara anggota Asean mungkin mempertimbangkan untuk melarang merger yang dapat menyebabkan penurunan persaingan secara signifikan dan dapat menghalangi persaingan yang efektif di dalam pasar yang bersangkutan, kecuali jika tidak dikecualikan. Merger menunjuk pada suatu situasi dimana dua ata lebih perusahaan, yang sebelumnya saling bergantung satu sama lain, bergabung menjadi satu, di mana satu atau lebih perusahaan memperoleh kendali atas satu atau lebih perusahaan, yang para pemimpinnya saling terkait satu dengan lainnya.

Dalam kaitannya dengan larangan merger anti persaingan Regional Guidance, menentukan bahwa suatu prosedur khusus (specific procedure) dapat dibentuk oleh badan pengaturan persaingan yang ditugasi menaksir merger, menyusul suatu pemberitahuan (secara sukarela atau bersifat perintah) oleh perusahaan yang dimerger, atau cara lain menyusul suatu complain atau melalui usul mereka sendiri. Dalam Bab ini, -Mandatory notification\| mencegah perusahaan dari penerapan transaksi sampai mereka telah menerima ijin merger dari badan pengaturan persaingan. Ini membantu menghindari suatu situasi di mana merger anti persaingan kemudian harus tunduk pada tindakan-tindakan dekonsentrasi yang sulit dan mahal yang dipaksakan oleh badan pengaturan persaingan. Sedangkan -Voluntary notification $\|$ mengijinkan pengusaha melakukan self-assesment merger mereka sendiri, untuk memutuskan jika mereka memberitahukan badan pengaturan persaingan untuk ijin merger. Hal ini membantu mengurangi biaya pengusaha sementara tidak menghalangi kekuasaan badan pengaturan persaingan menginvestigasi yang menimbulkan persaingan penting.

\section{4) Exemptions or exclusions from Application of Competition Law}

The implementation of competition policy should not prevent AMSs from pursuing other legitimate policies that may require derogations from competition policy principles. AMSs may have exemptions or exclusions aimed at specific industries or activities. The key rationale for granting exemptions or exclusions from competition law provisions to specific industries or activities includes strategic and national interest, security, public, economic and/or social considerations. For example, AMSs legislation may provide that:

a. Prohibitions may not apply to any undertaking entrusted with the operation of services of general economic interest or having the character of a revenue- producing monopoly in so far as the prohibition would obstruct the performance, in law or in fact, of the particular tasks assigned to that undertaking, such as guaranteeing universal access to various types of quality services at affordable prices.

b. Prohibitions may not apply to agreements or conduct to the extent to which such agreements or conduct are made in order to comply with a legal requirement, i.e., any requirement imposed by or under any written law or the judicial authority.

c. Prohibitions may not apply to agreements or conduct, when their application may result in a conflict with international obligations.

d. Prohibitions may not apply to agreements or conduct based on specific public policy grounds.

e. Prohibitions may not apply to the collective bargaining of workers over wages and conditions. 
b. Perundang-undangan dan Pedoman/Ketentuan Peralihan (Legislation and Guidelines/ Transitional Provisions;

Sebagaimana diuraikan di atas mengenai Perundang-undangan dan Pedoman/Ketentuan Peraliahan dalam Regional Guidelines diatur dalam Bab V. tentang hal ini ada empat hal yang diatur, yaitu :

1) Relevant Legislation and Guidelines for Competition Policy;

2) ReviewofNewor Existing Legislation;

3) Phased Implementationof Competition Law.

4) Transitional Provisions.

1) Relevant Legislation and Guidelines for Competition Policy.

Mengenai hal ini ditentukan bahwa bagi Negara-negara anggota Asean yang sudah atau belum memiliki peraturan persaingan usaha harus menyiapkan undang-undang yang jelas dan efektif pada saat penyusunan peraturan kebijakan persaingan mereka. Negara anggota dapat memilih untuk mengadopsi peraturan dasar yang berisi ketentuan umum dan memperkenalkan peraturan sekunder (seperti, peraturan dan pedoman) untuk menerapkan atau mengklarifikasi aspek operasional kebijakan, proses atau persoalan prosedur, dan menyiapkan pedoman tentang bagaimana badan pengawas persaingan akan menginterpretasikan hukum.

Peraturan perundang-undangan sekunder dapat diimplementasikan oleh pemerintah atau badan pengawas persaingan. Undang-undang tersebut mewajibkan badan pengawas persaingan untuk meminta konsultasi dengan public tentang peraturan-peraturan dan pedoman yang diusulkan, sebelum badan pengawas persaingan mengeluarkan peraturanperaturan dan pedoman. Perundang-undangan dan pedoman dapat mencakup ketentuan yang berkaitan dengan

- Definitions and interpretation.

- Extra-territorial application of competition law.

- Establishment and incorporation of the competition regulatory body.

- Functions, duties and powers of the competition regulatory body.

- Qualifications, terms of office of the main officials of the competition regulatory body.

- Administrative andfinancing matters of the competition regulatory body.

- Prohibition of anti-competitive agreements.

- Prohibition of abuse of dominant position

- Prohibition of anti-competitive mergers.

- Exemptions/exclusions from the application of the national competition law.

- Decision process for the prosecution of anti-competitive practices (anti-competitive agreements and abuse of dominant position and anti-competitive mergers) and exemption/authorisation of agreementorconductormerger.

- Provisions related to leniency and settlements.

- Investigation powers of the competition regulatory body and power to issue interim measures.

- The effect of an infringement decision by the competition regulatorybody.

- Enforcement powers of the competition regulatory body, (e.g., the power to impose sanctions, and remedies).

- Appeal process.

- Procedural offences (e.g., obstruction of investigations).

- Rights of private action (e.g., for an injured party to claim for compensation from the in fringing undertakings).

- Cooperation between the competition regulatory body and other local or overseas regulatory authorities (e.g., sharing of information, best practices, significant work accomplishment and capacity building).

- Preservation of secrecy (e.g., protection of information provided to the competition 
regulatory body and of the identity of complaints who wish to remain anonymous).

- Statutory time periods (e.g., for the competition regulatory body to issue a decision or for affected parties to file an appeal).

\section{2) Reviewof Newor Existing Legislation}

Mengenai hal ini ditentukan bahwa Negara-negara anggota ASEAN dapat mempertimbangkan apakah kebijakan persaingan harmonis atau konsisten dengan perundangundangan baru atau yang sudah ada, tetapi tidak terbatas pada peraturan perundang-undangan hak kekayaan intelektual, perdagangan yang fair, ketentuan atau peraturan sektoral atau undangundang perlindungan konsumen. Negara-negara anggota ASEAN dapat meninjau beberapa perundang-undangan baru atau telah ada yang menentukan pembatasan-pembatasan tentang persaingan sebagai suatu bagian integral dari kebijakan persaingan nasional.

Negara-negara anggota Asean dapat mempertimbangkan peninjauan secara komprehensif terhadap perundang-undangan yang berkaitan dengan persaingan (seperti, peraturan-peraturan pengawasan harga) untuk menentukan apakah persaingan yang dikhawatirkan dapat ditangani dengan cara-cara pembatasan yang sedikit potensial (seperti monitoring harga).

\section{3) Phased Implementationof Competition Law.}

Negara-negara anggota Asean dapat mempertimbangkan penerapan hokum persaingan secara bertahap. Misalnya, larangan-larangan yang berbeda dapat diimplementasikan pada jangka waktu yang realistis, larangan tentang perjanjian-perjanjian anti persaingan dapat diperkenalkan lebih dahulu, atau bersama dengan larangan penyalahgunaan posisi dominan, dan larangan merger anti persaingan dapat diperkenalkan saat terakhir, karena kompleksitas dalam menganalisis kasus merger.

\section{4) TransitionalProvisions}

Negara-negara anggota ASEAN juga dapat mempertimbangkan ketentuan-ketentuan peralihan atau clausula sunset. Ketentuan peralihan menunjuk kepada ketentuan perndangundangan yang mengatur aplikasi undang-undang baru selama jangka waktu yang ditentukan, seperti persiapan bahwa badan pengawas persaingan tidak menjatuhkan hukuman untuk perjanjian-perjanjian anti persaingan yang terjadi pada permulaan atau segera setelah larangan itu diperkenalkan di dalam jangka waktu yang ditentukan.-Sunset Clausulall menunjuk pada ketentuan perundang-undangan yang mengijinkan perjanjian anti persaingan atau melakukan untuk menikmati imunitas terhadap hukuman dan sanksi oleh badan pengawas persaingan, sampai jangka waktu yang ditentukan. Hal ini akan memberikan waktu kepada pihak-pihak untuk merundingkan kembali atau merestrukturisasi perusahaan mereka guna memenuhi ketentuan-ketentuan baru sepanjang mereka mewakili suatu permulaan kebiasaan dari hokum yang mendahului mereka. Ini adalah sangat penting dimana perbuatan itu sekali diijinkan atau ditoleransi menjadi dilarang atau dikriminalisasi.

\section{Upaya Harmonisasi Undang-Undang Persaingan Negara-negara Anggota ASEAN}

Di atas telah dikemukakan bahwa sebelum cetak biru disahkan pada tahun 2007, dan The ASEAN Regional Guidelines on Competition Policy (Regional Guidelines) pada tahun 2010, Negara anggota Asean sudah memiliki peraturan perundang-undangan yang berkaitan dengan persaingan usaha antara lain: (i) Indonesia, yaitu UU No. 5 Tahun 1999 tentang Larangan Praktek Monopoli dan Persaingan Usaha Tidak Sehat; (ii) Malaysia, Laws of M alaysia, Act 712 Competition Act 2010; (iv) Thailand, yaitu Competition Act B.E 2542 (1999) yang kemudian diamandemen dengan Act B.E 2560 (2017); Guna mengkaji apakah perundangundangan tersebut sudah selaras (harmonis) dengan The ASEAN Regional Guidelines on Competition Policy (Regional Guidelines) khususnya yang diatur dalam Bab V yaitu Perundang-undangan dan Pedoman/Ketentuan Peralihan (Legislation and Guidelines/ Transitional Provisions), maka penulis akan membandingkan perundang-undangan yang dimiliki ketiga negara anggota ASEAN tersebut dengan indikator yang ditetapkan dalam Regional Guidelines. 
a. Indonesia, yaitu UU No. 5 Tahun 1999 tentang Larangan Praktek Monopoli dan Persaingan Usaha Tidak Sehat

\begin{tabular}{|c|c|c|c|}
\hline & $\begin{array}{c}\text { Indikator dalam } \\
\text { Regional } \\
\text { Guidelines } \\
\end{array}$ & UU No. 5 tahun 1999 & $\begin{array}{l}\text { Harmonis/ } \\
\text { Belum }\end{array}$ \\
\hline 1) & Definisi dan interpretasi & $\begin{array}{l}\text { Diatur pada Bab I Ketentuan Umum, } \\
\text { berisi definisi-2 }\end{array}$ & $\begin{array}{l}\text { Belum } \\
\text { memuat } \\
\text { interpretasi }\end{array}$ \\
\hline 2) & $\begin{array}{l}\text { Penerapan hokum persaingan } \\
\text { secara eks-tra Territorial }\end{array}$ & Belum mengatur & $\begin{array}{l}\text { Belum } \\
\text { mengatur }\end{array}$ \\
\hline 3) & $\begin{array}{l}\text { Pendirian dan penggabungan } \\
\text { badan pengawas persaingan }\end{array}$ & $\begin{array}{l}\text { Diatur pada Bab VI tentang Komisi } \\
\text { Pengawas Persaingan Usaha; Kepres No. } \\
\text { 75/1999 jo Perpres No. 80/2008, KPPU }\end{array}$ & $\begin{array}{l}\text { Belum } \\
\text { mengatur } \\
\text { kerjasama } \\
\text { antar badan } \\
\text { pengawas }\end{array}$ \\
\hline 4) & $\begin{array}{l}\text { Fungsi, tugas dan wewenang } \\
\text { badan pengawas persaingan }\end{array}$ & $\begin{array}{l}\text { Diatur pada Bab VI, Bagian III dan } \\
\text { IV, dan Kepres No. } 75 / 1999 \text { jo } \\
\text { Perpres No. } \\
\text { 80/2008 tentang KPPU } \\
\end{array}$ & Sudah harmonis \\
\hline 5) & $\begin{array}{l}\text { Kualifikasi, syarat jabatan } \\
\text { pejabat utama badan } \\
\text { pengawas persaingan }\end{array}$ & $\begin{array}{l}\text { Diatur pada Bab VI, Bagian II, dan } \\
\text { Kepres No. } 75 / 1999 \text { jo } \\
\text { Perpres No. 80/2008, tentang KPPU }\end{array}$ & Sudah harmonis \\
\hline 6) & $\begin{array}{l}\text { Masalah administrasi dan } \\
\text { pembiayaan badan pengawas } \\
\text { persaingan }\end{array}$ & $\begin{array}{l}\text { Diatur pada Bab VI, Bagian } \\
\text { V, juga Perpres No. } 80 / 2008 \text { tentang } \\
\text { KPPU }\end{array}$ & Sudah harmonis \\
\hline 7) & $\begin{array}{l}\text { Larangan perjanjian anti } \\
\text { persaingan }\end{array}$ & $\begin{array}{l}\text { Diatur pada Bab III, tentang Perjanjian } \\
\text { yang dilarang, Bagian I - X, } \\
\text { Oligopoli, Penetapan harga, } \\
\text { Pembagian wilayah (horizontal } \\
\text { /vertical), Pemboikotan, Kartel, Trust, } \\
\text { Oligopsoli, Integrasi vertical, } \\
\text { Perjanjian tertutup, Perjanjian dengan } \\
\text { pihak luar negeri }\end{array}$ & Sudah harmonis \\
\hline 8) & $\begin{array}{l}\text { Larangan } \\
\text { penyalahgunaan posisi } \\
\text { dominan }\end{array}$ & $\begin{array}{l}\text { Diatur pada Bab V, Bagian I- III, } \\
\text { Umum, larangan-larangan Jabatan } \\
\text { rangkap, Pemilikan saham }\end{array}$ & Sudah harmonis \\
\hline 9) & $\begin{array}{l}\text { Larangan merger anti } \\
\text { persaingan }\end{array}$ & $\begin{array}{l}\text { Diatur pada Bab V, tentang Posisi } \\
\text { Dominan, Bagian IV tentang Larangan } \\
\text { Penggabungan, Peleburan, dan } \\
\text { pengambilalihan. Diatur dalam PP No. } \\
57 / 2010 \text { tentang penggabungan atau } \\
\text { Peleburan badan Usaha dan Pengambil- } \\
\text { alihan Saham Perusahaan yang dapat } \\
\text { mengakibatkan terjadinya Praktik } \\
\text { Mono-poli dan Persaingan Usaha Tidak } \\
\text { Sehat; Peraturan KPPU No. } 2 \text { Tahun } \\
2013\end{array}$ & Sudah harmonis \\
\hline
\end{tabular}




\begin{tabular}{|c|c|c|}
\hline $\begin{array}{l}\text { 10) Pengecualian dari penerapan } \\
\text { hukum persaingan nasional }\end{array}$ & $\begin{array}{l}\text { Diatur pada Bab IX, tentang Ketentuan } \\
\text { Lain, Pasal 50-51. }\end{array}$ & Sudah harmonis \\
\hline $\begin{array}{l}\text { 11) Proses keputusan untuk } \\
\text { penuntutan praktik anti } \\
\text { persaingan(kesepakatan anti } \\
\text { persaingan dan } \\
\text { penyalahgunaan posisi } \\
\text { dominan dan merger anti } \\
\text { persaingan) dan } \\
\text { pembebasan/otorisasi } \\
\text { perjanjian atau penggabungan } \\
\text { usaha }\end{array}$ & $\begin{array}{l}\text { Diatur pada Bab VII, tentang Tata } \\
\text { Cara Penanganan Perkara, Pasal } 38 \text { - } \\
46 . \\
\text { Mengatur secara umum saja, bila terjadi } \\
\text { pelanggaran terhadap undang-undang } \\
\text { ini dapat melaporkan secara tertulis } \\
\text { kepada Komisi dengan keterangan yang } \\
\text { jelas tentang telah terjadinya } \\
\text { pelanggaran, dengan menyertakan } \\
\text { identitas pelapor (pasal } 38 \text { ayat } 1 \text { ). } \\
\text { Peraturan KPPU No. } 1 \text { Tahun 2010 } \\
\text { tentang Tata Cara Penanganan perkara. }\end{array}$ & $\begin{array}{l}\text { Sudah } \\
\text { Harmonis }\end{array}$ \\
\hline $\begin{array}{l}\text { 12) Ketentuan terkait leniency dan } \\
\text { settlements }\end{array}$ & Tidak mengatur & $\begin{array}{l}\text { Belum } \\
\text { harmonis }\end{array}$ \\
\hline $\begin{array}{l}\text { 13) Kekuatan investigasi badan } \\
\text { pengawas persaingan dan } \\
\text { kewenangan untuk } \\
\text { mengeluarkan tindakan } \\
\text { penyelidikan sementara }\end{array}$ & $\begin{array}{l}\text { Diatur dalam Bab VII, dan Peraturan } \\
\text { KPPU No. } 1 \text { Tahun } 2010 \text { tentang Tata } \\
\text { Cara Penanganan perkara }\end{array}$ & Sudah harmonis \\
\hline $\begin{array}{l}\text { 14) Dampak dari keputusan terkait } \\
\text { pelanggaran yang dikeluarkan } \\
\text { badan pengawas persaingan }\end{array}$ & Tidak mengatur & $\begin{array}{l}\text { Belum } \\
\text { Harmonis }\end{array}$ \\
\hline $\begin{array}{l}\text { 15) Kekuatan hokum badan } \\
\text { pengawas persaingan, } \\
\text { (misalnya, kekuatan untuk } \\
\text { menjatuhkan sanksi, dan } \\
\text { pemulihan) }\end{array}$ & $\begin{array}{l}\text { Diatur pada Bab VII, tentang Tata cara } \\
\text { penanganan perkara, pasal } 43 \text { dan } 44 \\
\text { dan Peraturan } \\
\text { KPPU No. } 1 \text { Tahun } 2010 \\
\text { tentang Tata Cara Penanganan } \\
\text { perkara,Bab IV, pasal 58-59. }\end{array}$ & Sudah harmonis \\
\hline 16) Proses banding & $\begin{array}{l}\text { Diatur pada Bab VII, Mengajukan } \\
\text { keberatan melalui PN Jakarta Pusat, } \\
\text { dan Kasasi ke Mahkamah Agung, Pasal } \\
44 \text { dan } 45\end{array}$ & Sudah harmonis \\
\hline $\begin{array}{l}\text { 17) Pelanggaran prosedural } \\
\text { (misalnya menghalangi } \\
\text { penyidikan) }\end{array}$ & Tidak mengatur & $\begin{array}{l}\text { Belum } \\
\text { harmonis }\end{array}$ \\
\hline $\begin{array}{l}\text { 18) Hak pribadi dalam bertindak } \\
\text { (misalnya, bagi pihak yang } \\
\text { dirugikan menuntut ganti rugi } \\
\text { pelanggaran dari pihak yang } \\
\text { bersalah) }\end{array}$ & Tidak mengatur & $\begin{array}{l}\text { Belum } \\
\text { harmonis }\end{array}$ \\
\hline
\end{tabular}




\begin{tabular}{|c|c|c|}
\hline $\begin{array}{l}\text { 19) Kerjasama antar badan } \\
\text { pengawas persaingan dan } \\
\text { otoritas pengatur lokal atau } \\
\text { luar negeri (seperti berbagi } \\
\text { informasi dsb) }\end{array}$ & Tidak mengatur & $\begin{array}{l}\text { Belum } \\
\text { harmonis }\end{array}$ \\
\hline $\begin{array}{l}\text { 20) Menjaga kerahasiaan } \\
\text { (misalnya, perlindungan } \\
\text { informasi yang diberikan } \\
\text { kepada badan pengawas } \\
\text { persaingan dan identitas } \\
\text { penggugat yang ingin anonym) }\end{array}$ & $\begin{array}{l}\text { Diatur pada Bab VII, Pasal } 38 \text { (3), dan } \\
\text { Pasal } 39 \text { ayat } 3 .\end{array}$ & Sudah harmonis \\
\hline $\begin{array}{l}\text { 21) Periode waktu yang ditentukan } \\
\text { (misalnya bagi badan } \\
\text { pengawas persaingan memiliki } \\
\text { kewajiban untuk } \\
\text { mengeluarkan keputusan } \\
\text { kepada pihak yang terkena } \\
\text { dampak untuk mengajukan } \\
\text { banding) }\end{array}$ & $\begin{array}{l}\text { Bab VII, Pasal } 44 \text { (2), dan } 45 \text { (4) dan } \\
\text { Peraturan KPPU No. } 1 \text { Tahun } 2010 \\
\text { tentang Tata Cara Penanganan perkara, } \\
\text { Pasal } 65 \text { tentang upaya hokum } \\
\text { mengajukan keberatan ke Pengadilan } \\
\text { Negeri. }\end{array}$ & Sudah harmonis \\
\hline
\end{tabular}

Berdasarkan hasil analisis terhadap peraturan perundang-undangan yang berkaitan dengan Larangan Praktek Monopoli dan Persaingan Usaha Tidak Sehat di Indonesia sebagaimana diuraikan di atas, diketahui bahwa ada enam indicator yang digariskan dalam Regional Guideline yang belum diatur, yaitu (i) penerapan hokum persaingan secara ekstra territorial, (ii) ketentuan terkait leniency dan settlement, (iii) dampak dari keputusan yang berkaitan dengan pelanggaran yang dikeluarkan badan pengawas persaingan, (iv) pelanggaran procedural (menghalangi penyidikan), (v) Hak pribadi dalam bertindak (misalnya, bagi pihak yang dirugikan menuntut ganti rugi pelanggaran dari pihak yang bersalah), dan (vi) Kerjasama antar badan pengawas persaingan dan otoritas pengatur local atau luar negeri (seperti berbagi informasi dsb).

b. Laws of M alaysia, Act 712 Competition Act 2010 .

\begin{tabular}{|l|l|l|}
\hline \multicolumn{1}{|c|}{$\begin{array}{c}\text { Indikator dalam } \\
\text { Regional Guidelines }\end{array}$} & \multicolumn{1}{|c|}{ Competition Act 2010 } & $\begin{array}{l}\text { Harmonis/ } \\
\text { Belum }\end{array}$ \\
\hline 1) & Definisi dan interpretasi & $\begin{array}{l}\text { Diatur pada Bagian I } \\
\text { Preliminary, Clause (1) Short title and } \\
\text { commencement, (2) Interpretatio }\end{array}$ \\
\hline $\begin{array}{l}\text { 2) } \\
\begin{array}{l}\text { Penerapan hukum } \\
\text { persaingan secara } \\
\text { ekstra territorial }\end{array}\end{array}$ & Diatur pada Bagian I, Clause (3) Aplication \\
\hline $\begin{array}{l}\text { Pendirian dan } \\
\text { penggabungan badan } \\
\text { pengawas persaingan }\end{array}$ & $\begin{array}{l}\text { Diatur pada Bagian I, Clause (2) } \\
\text { Interpretation, diatur lebih lanjut dalam } \\
\text { Competition Commission Act 2010, Part II, } \\
\text { Establishmentof the Competition Commission. } \\
\text { Tidak mengatur tentang penggabungan badan } \\
\text { pengawas persaingan }\end{array}$ & Harmonis \\
\hline
\end{tabular}




\begin{tabular}{|c|c|c|c|}
\hline & $\begin{array}{l}\text { Fungsi, tugas dan } \\
\text { wewenang badan } \\
\text { pengawas persaingan }\end{array}$ & $\begin{array}{l}\text { Diatur dalam Competition } \\
\text { Commission Act 2010, Part III,Section } \\
\text { 16-17 }\end{array}$ & Harmonis \\
\hline 5) & $\begin{array}{l}\text { Kualifikasi, syarat } \\
\text { jabatan pejabat utama } \\
\text { badan pengawas } \\
\text { persaingan }\end{array}$ & $\begin{array}{l}\text { Diatur dalam Competition Commission Act } \\
2010, \text { Part IV Provision Relating to Employees } \\
\text { of the Commission, Section (20) Chief Executive } \\
\text { Officer }\end{array}$ & Harmonis \\
\hline 6) & $\begin{array}{l}\text { Masalah } \\
\text { administrasi dan } \\
\text { pembiayaan badan } \\
\text { pengawas } \\
\text { persaingan }\end{array}$ & $\begin{array}{l}\text { Diatur dalam Competition Commission Act } \\
\text { 2010, Part V Finance, Section 27-37. }\end{array}$ & Harmonis \\
\hline 7) & $\begin{array}{l}\text { Larangan perjanjian anti } \\
\text { persaingan }\end{array}$ & $\begin{array}{l}\text { Diatur pada Bagian II Anti-Competitif } \\
\text { Practices, Chapter } 1 \text { Anti-competitive } \\
\text { agreement, Clause (4)Prohibited horizontal } \\
\text { and vertical agreement, (5) Relief of liability, } \\
\text { (6) individual exemp-tion, (7) Cancellation or } \\
\text { variation of individual exemption, (8)Block } \\
\text { exemption, (9)Procedure for block exemption. }\end{array}$ & Sudah harmonis \\
\hline 8) & $\begin{array}{l}\text { Larangan } \\
\text { penyalahgunaan } \\
\text { posisi dominan }\end{array}$ & $\begin{array}{l}\text { Diatur pada Chapter } 2 \text { Abuse of Dominant } \\
\text { position, Clause (10) Abuse of Dominant } \\
\text { position is prohibited, (11)Power to conduct } \\
\text { market review, (12)Determination of market } \\
\text { review }\end{array}$ & Sudah harmonis \\
\hline 9) & $\begin{array}{l}\text { Larangan merger anti } \\
\text { persaingan }\end{array}$ & Tidak mengatur & Belum harmonis \\
\hline 10 & $\begin{array}{l}\text { Pengecualian dari } \\
\text { penerapan hukum } \\
\text { persaingan nasional }\end{array}$ & $\begin{array}{l}\text { Diatur pada Chapter } 4 \text { Exclusion, Clause (13) } \\
\text { Exclusion }\end{array}$ & Sudah harmonis \\
\hline 11 & $\begin{array}{l}\text { Proses keputusan untuk } \\
\text { penuntutan praktik anti } \\
\text { persaingan(kesepakatan } \\
\text { anti persaingan dan } \\
\text { penyalahgunaan posisi } \\
\text { dominan dan merger } \\
\text { anti persaingan) dan } \\
\text { pembebasan/otorisasi } \\
\text { perjanjian atau } \\
\text { penggabungan usaha }\end{array}$ & $\begin{array}{l}\text { Diatur pada Part IV Decision by the } \\
\text { Commission, Section 35-43 }\end{array}$ & Sudah harmonis \\
\hline & $\begin{array}{l}\text { Ketentuan terkait } \\
\text { leniency dan settlements }\end{array}$ & Tidak mengatur & Belum harmonis \\
\hline & $\begin{array}{l}\text { Kekuatan investigasi } \\
\text { badan pengawas } \\
\text { persaingan dan } \\
\text { kewenangan untuk }\end{array}$ & $\begin{array}{l}\text { Diatur pada Part III Investigation and } \\
\text { Enforcement, Clause (14) Investigation by } \\
\text { Commission, (17) Power of } \\
\text { investigation, (18) Power to require provision }\end{array}$ & Sudah harmonis \\
\hline
\end{tabular}




\begin{tabular}{|c|c|c|}
\hline $\begin{array}{l}\text { mengeluarkan tindakan } \\
\text { penyelidikan sementara }\end{array}$ & of information & \\
\hline $\begin{array}{l}\text { 14) Dampak dari keputusan } \\
\text { terkait pelanggaran } \\
\text { yang dikeluarkan badan } \\
\text { pengawas persaingan }\end{array}$ & $\begin{array}{l}\text { Diatur dalam Part V, Section } \\
\text { (60) Pro-tection against suit and legal } \\
\text { procee-dings }\end{array}$ & Sudah harmonis \\
\hline $\begin{array}{l}\text { 15) Kekuatan hokum badan } \\
\text { pengawas persaingan, } \\
\text { (misalnya, kekuatan } \\
\text { untuk menjatuhkan } \\
\text { sanksi, dan pemulihan) } \\
\end{array}$ & $\begin{array}{l}\text { Diatur dalam Part IV, Decision by The } \\
\text { Commission, Section } 42\end{array}$ & Sudah harmonis \\
\hline 16) Proses banding & $\begin{array}{l}\text { Diatur pada Part V Competition Appeal } \\
\text { Tribunal, Section } 44-59\end{array}$ & Sudah harmonis \\
\hline $\begin{array}{l}\text { 17) Pelanggaran procedural } \\
\text { (misalnya menghalangi } \\
\text { penyidikan) }\end{array}$ & $\begin{array}{l}\text { Diatur pada Part III, Section (32) Obstruction, } \\
\text { (33) Tipping off. (34) Threat and reprisal is } \\
\text { prohibited }\end{array}$ & Sudah harmonis \\
\hline $\begin{array}{l}\text { 18) Hak pribadi dalam } \\
\text { bertindak (misalnya, } \\
\text { bagi pihak yang } \\
\text { dirugikan menuntut } \\
\text { ganti rugi pelanggaran } \\
\text { dari pihak yang } \\
\text { bersalah) }\end{array}$ & $\begin{array}{l}\text { Diatur pada Part VI General, Section (64) } \\
\text { Rights of private action }\end{array}$ & Sudah harmonis \\
\hline $\begin{array}{l}\text { 19) Kerjasama antar badan } \\
\text { pengawas persaingan } \\
\text { dan otoritas pengatur } \\
\text { lokal atau luar negeri } \\
\text { (seperti berbagi } \\
\text { informasi dsb) }\end{array}$ & $\begin{array}{l}\text { Diatur pada Competition Act 2010, Part VI } \\
\text { General, Section (39) Inter-working with } \\
\text { other authorities }\end{array}$ & Sudah harmonis \\
\hline \begin{tabular}{|l|} 
20) Menjaga kerahasiaan \\
(misalnya, perlindungan \\
informasi yang \\
diberikan kepada badan \\
pengawas persaingan \\
dan identitas penggugat \\
yang ingin anonym) \\
\end{tabular} & $\begin{array}{l}\text { Diatur pada Part III Investigation and } \\
\text { Enforcement, Section (21) Confidentiality }\end{array}$ & Sudah harmonis \\
\hline \begin{tabular}{|l|} 
21) Periode waktu yang \\
ditentukan (misalnya \\
bagi badan pengawas \\
persaingan memiliki \\
kewajiban untuk \\
mengeluarkan \\
keputusan kepada pihak \\
yang terkena \\
dampak untuk \\
mengajukan banding)
\end{tabular} & $\begin{array}{l}\text { Diatur pada Part V Competition Appeal } \\
\text { Tribunal, Section (51) }\end{array}$ & Sudah harmonis \\
\hline
\end{tabular}

Berdasarkan hasil analisis terhadap peraturan perundang-undangan Malaysia yaitu Competition Act 210 (Act 712) dan Commission Act 2010 (Act 713) sebagaimana diuraikan di atas, diketahui bahwa hanya ada dua indicator yang digariskan dalam Regional Guideline yang belum diatur, yaitu (i), Larangan merger anti persaingan, dan (ii) ketentuan terkait leniency dan settlement. 
c. Singapura, yaitu Act 40 of 2005 - Competition (Amendment) Act 2005

\begin{tabular}{|c|c|c|c|}
\hline \multicolumn{2}{|r|}{$\begin{array}{c}\text { Indikator dalam } \\
\text { Regional Guidelines }\end{array}$} & \multirow{2}{*}{$\begin{array}{l}\begin{array}{l}\text { Act } \mathbf{4 0} \text { of } 2005 \text { - Competition } \\
\text { (Amendment) Act } 2005\end{array} \\
\text { Part I. Preliminary, section (1) Short title, } \\
\text { (2) Interpretasi }\end{array}$} & \multirow{2}{*}{\begin{tabular}{|l|} 
Harmonis/ \\
Belum
\end{tabular}} \\
\hline & Definisi dan interpretasi & & \\
\hline 2) & $\begin{array}{l}\text { Penerapan hukum } \\
\text { persaingan } \\
\text { secara ekstra } \\
\text { territorial }\end{array}$ & Tidak mengatur & Belum harmonis \\
\hline 3) & $\begin{array}{l}\text { Pendirian dan } \\
\text { penggabungan badan } \\
\text { pengawas persaingan }\end{array}$ & $\begin{array}{l}\text { Part II. Competition ommission of Singapore. } \\
\text { Division } 1 \text { - Establishment, incorporation } \\
\text { and constitution of Commission. } \\
\text { Establishment and incorporation of } \\
\text { Competition Commission of Singapore, } \\
\text { section (3) }\end{array}$ & Sudah harmonis \\
\hline 4) & $\begin{array}{l}\text { Fungsi, tugas dan } \\
\text { wewenang badan } \\
\text { pengawas persaingan }\end{array}$ & $\begin{array}{l}\text { Division } 2-\text { Functions, duties and } \\
\text { po-wers of Commission, section (6) and (7) }\end{array}$ & Sudah harmonis \\
\hline 5) & $\begin{array}{l}\text { Kualifikasi, syarat } \\
\text { jabatan pejabat utama } \\
\text { badan pengawas } \\
\text { persaingan }\end{array}$ & $\begin{array}{l}\text { Division } 3 \text { Provisions relating to staff. } \\
\text { Appointment of Chief Executive and other } \\
\text { employees, etc.section (10) }\end{array}$ & Sudah harmonis \\
\hline 6) & $\begin{array}{l}\text { Masalah administrasi } \\
\text { dan pembiayaan badan } \\
\text { pengawas persaingan }\end{array}$ & $\begin{array}{l}\text { Division } 4 \text { - Financial provisions. Section } \\
\text { (11) Financial year, Annual estimates (12), } \\
\text { Moneys recovered or collected by } \\
\text { Commission (13), Grants in-aid (14), Power } \\
\text { to borrow (15), etc. }\end{array}$ & Sudah harmonis \\
\hline 7) & $\begin{array}{l}\text { Larangan } \\
\text { perjanjian anti } \\
\text { persaingan }\end{array}$ & $\begin{array}{l}\text { Part III. Competition, Division } 2 \\
\text { - Agreements, etc., preventing, } \\
\text { restrict-ting or distorting } \\
\text { competition, section (34). }\end{array}$ & Sudah harmonis \\
\hline 8) & $\begin{array}{l}\text { Laranganpenyalahgunaa } \\
\mathrm{n} \text { posisi dominan }\end{array}$ & $\begin{array}{l}\text { Part III. Competition, Division3, } \\
\text { Abuse of dominant position General, } \\
\text { section (47). }\end{array}$ & Sudah harmonis \\
\hline & $\begin{array}{l}\text { Larangan merger } \\
\text { anti persaingan }\end{array}$ & $\begin{array}{l}\text { Part III. Competition, Division 1, General, } \\
\text { Application of Part section (34) and Division } \\
4 \\
\text { Merger, section (54). }\end{array}$ & Sudah harmonis \\
\hline & $\begin{array}{l}\text { Pengecualian dari } \\
\text { penerapan hokum } \\
\text { persaingan nasional }\end{array}$ & $\begin{array}{l}\text { Part III. Competition, Division 2, section (35) } \\
\text { Excluded agreements }\end{array}$ & Sudah harmonis \\
\hline & $\begin{array}{l}\text { Proses keputusan untuk } \\
\text { penuntutan praktik } \\
\text { anti persaingan } \\
\text { (kesepakatan anti } \\
\text { persaingan dan } \\
\text { penyalahgunaan } \\
\text { posisi dominan dan } \\
\text { merger anti } \\
\text { persaingan) dan }\end{array}$ & $\begin{array}{l}\text { Part III. Competition, Division V } \\
\text { Enforcement. Section( } 68) \text { Decision of } \\
\text { Commission upon completion of } \\
\text { investigation }\end{array}$ & Sudah harmonis \\
\hline
\end{tabular}




\begin{tabular}{|c|c|c|}
\hline $\begin{array}{l}\text { pembebasan/otorisasi } \\
\text { perjanjian atau } \\
\text { penggabungan usaha }\end{array}$ & & \\
\hline $\begin{array}{l}\text { 12) Ketentuan terkait } \\
\text { leniency dan settlements }\end{array}$ & Tidak mengatur & Belum harmonis \\
\hline \begin{tabular}{|l|} 
13) Kekuatan investigasi \\
badan pengawas \\
persaingan dan \\
kewenangan untuk \\
mengeluarkan tindakan \\
penyelidikan sementara \\
\end{tabular} & $\begin{array}{l}\text { Part III. Competition, Division V } \\
\text { Enforcement, section (62), (63), } \\
\text { (64), (65), dan 67. And Second Schedule, } \\
\text { Power of Commission }\end{array}$ & Sudah harmonis \\
\hline $\begin{array}{l}\text { 14) Dampak dari keputusan } \\
\text { terkait pelanggaran yang } \\
\text { dikeluarkan badan } \\
\text { pengawas persaingan } \\
\end{array}$ & $\begin{array}{l}\text { Part III. Competition, Division } 3 \text { Abuse of } \\
\text { Dominant, section (53) } \\
\text { Effect of decision that section } 47 \text { prohibition } \\
\text { has not been infringed. }\end{array}$ & Sudah harmonis \\
\hline $\begin{array}{l}\text { 15) Kekuatan hokum badan } \\
\text { pengawas persaingan, } \\
\text { (misalnya, kekuatan } \\
\text { untuk menjatuhkan } \\
\text { sanksi, dan pemulihan) } \\
\end{array}$ & $\begin{array}{l}\text { Part III. Competition, Division V } \\
\text { Enforcement,section(68) Decision of } \\
\text { Commission upon completion of } \\
\text { investigation, section (69) Enfor-cement of } \\
\text { decision of Commission }\end{array}$ & Sudah harmonis \\
\hline 16) Proses banding & $\begin{array}{l}\text { Part IV Appeals, Division } 1 \text { General, Appeals } \\
\text { decision (71), Division } 2 \text { Competition } \\
\text { Appeals Board (72) Powers and decisions of } \\
\text { Board (73) Appeals to High Court and Court } \\
\text { of Appeal (74). }\end{array}$ & Sudah harmonis \\
\hline $\begin{array}{l}\text { 17) Pelanggaran procedural } \\
\text { (misalnya menghalangi } \\
\text { penyidikan) }\end{array}$ & $\begin{array}{l}\text { Part V Offences, section } 75-78 . \text { Section (78) } \\
\text { Obstruction of officer of Commission, etc. Any } \\
\text { person who refuses to give access to, or } \\
\text { assaults, hinders or delays any member, } \\
\text { officer, employee or agent of the Commission } \\
\text { authorised to act for or assist the Commission, } \\
\text { or any inspector or person assisting an } \\
\text { inspector, in the discharge of his duties under } \\
\text { this Act shall be guilty of an offence. }\end{array}$ & Sudah harmonis \\
\hline $\begin{array}{l}\text { 18) Hak pribadi dalam } \\
\text { bertindak (misalnya, } \\
\text { bagi pihak yang } \\
\text { dirugikan menuntut } \\
\text { ganti rugi pelanggaran } \\
\text { dari pihak yang } \\
\text { bersalah) } \\
\end{array}$ & $\begin{array}{l}\text { Part VI Miscellaneous, section } \\
\text { (86) Rights of private action. }\end{array}$ & Sudah harmonis \\
\hline $\begin{array}{l}\text { 19) Kerjasama antar badan } \\
\text { pengawas persaingan } \\
\text { dan otoritas pengatur } \\
\text { local atau luar negeri } \\
\text { (seperti berbagi } \\
\text { informasi dsb) } \\
\end{array}$ & $\begin{array}{l}\text { Part VI, section (87) Co-operation between } \\
\text { Commission and other regulatory authorities } \\
\text { on competition matters. Section (88) Co- } \\
\text { operation between Commission and foreign } \\
\text { competition bodies. }\end{array}$ & Sudah harmonis \\
\hline \begin{tabular}{|l|} 
20) Menjaga kerahasiaan \\
(misalnya, perlindungan \\
informasi yang \\
diberikan kepada badan \\
pengawas persaingan \\
\end{tabular} & $\begin{array}{l}\text { Part VI. Section (89) Preservation } \\
\text { of secrecy }\end{array}$ & Sudah harmonis \\
\hline
\end{tabular}




\begin{tabular}{|l|l|l|}
\hline $\begin{array}{l}\text { dan identitas penggugat } \\
\text { yang ingin anonym) }\end{array}$ & \\
\hline 21) Periode waktu yang & $\begin{array}{l}\text { Part III. Competition, Division V } \\
\text { Enforcement, section (70) Notifica-tion, The } \\
\text { ditentukan (misalnya } \\
\text { bagi badan pengawas } \\
\text { persaingan memiliki }\end{array}$ & Sudah harmonis \\
kewajiban untuk & $\begin{array}{l}\text { making any decision or direction under this } \\
\text { Part, notify any person affected by such } \\
\text { mengeluarkan }\end{array}$ & \\
keputusan kepada pihak & decision or \\
yang terkena dampak & direction. & \\
untuk mengajukan & \\
banding) & & \\
\hline
\end{tabular}

Berdasarkan hasil analisis terhadap peraturan perundang-undangan Singapura, yaitu Act 40 of 2005 - Competition (Amendment) Act 2005 sebagaimana diuraikan di atas, diketa- hui bahwa hanya ada dua indicator yang digariskan dalam Regional Guideline yang belum diatur, yaitu (i) Penerapan hokum persaingan secara ekstra territorial, dan (ii) ketentuan terkait leniency dan settlement.

\section{Penutup}

Apabila kita membandingkan Competition Act 210 (Act 712) dan Commission Act 2010 (Act 713) yang dimiliki oleh Malaysia, dan Act 40 of 2005 - Competition (Amendment) Act 2005 yang dimiliki oleh Singapura, dengan UU No. 5 Tahun 1999 tentang Larangan Praktek Monopoli dan Persaingan Usaha Tidak Sehat, dan peraturan pelaksanaan lainnya yang dimiliki oleh Indonesia, dalam kaitannya dengan upaya harmonisasi sesuai Regional Guideline sebagai pedoman dalam penyusunan perundang-undangan persaingan usaha di Negara-negara ASEAN, maka undang-undang persaingan Malaysia dan Singapura lebih mendekati harmonis ketimbang peraturan perundang-undangan yang dimiliki oleh Indonesia. Untuk itu perlu dilakukan upaya amandemen terhadap UU No. 5 Tahun 1999 tentang Larangan Praktek Monopoli dan Persaingan Usaha Tidak Sehat sesuai dengan Regional Guideline, guna merealisasikan Asean Blueprint dalam rangka Komunitas Ekonomi Asean yang sudah berlangsung sejak tahun2015.

\section{DAFTAR PUSTAKA}

\section{A. Peraturan Perundang-Undangan}

Keputusan Presiden Republik Indonesia No. 75 Tahun 1999 tentang Komisi Pengawas Persaingan Usaha.

Peraturan Komisi Pengawas Persaingan Usaha No. 1 Tahun 2010 tentang Tata Cara Penanganan Perkara.

Peraturan Pemerintah No. 57 Tahun 2010 tentang Penggabungan atau Peleburan badan Usaha dan Pengambilalihan Saham Perusahaan yang Dapat Mengakibatkan Terjadinya Praktik Monopoli dan Persaingan Usaha Tidak Sehat.

\section{B. Sumber Lain}

ditc_ccpb_ncl_Singapore_en_pdf. Act 40 of 2005 - Competition (Amendment) Act 2005. https://www.icao.int Document ASE...Asean Regional Guidelines on Competition Policy www.apeccp.org.tw Organization. Malaysia Commission Act 2010 (Act 713) www.asean.org November/aec-page. Blueprint 2025 -Asean.

www.kppu.go.id UU_No.5.pdf. UU No. 5 Tahun 1999 tentang Larangan Praktek Monopoli dan Persaingan Usaha Tidak Sehat, www.mycc.gov.mysites default files. Malaysia Competition Act 210 (Act 712). 
